\title{
AN ANALYSIS OF THE RIGHT OF A MUSLIM CHILD BORN OUT OF WEDLOCK TO INHERIT FROM HIS OR HER DECEASED PARENT IN TERMS OF THE LAW OF SUCCESSION: A SOUTH AFRICAN CASE STUDY
}

\author{
Muneer Abduroaf
}

$B A$ LLB LLM LLD

Senior Lecturer, Department of Criminal Justice and Procedure, University of the Western Cape

\section{SUMMARY}

This article analyses the right of a Muslim child born out of wedlock to inherit from his or her deceased parent in terms of the law of succession within the South African context. $^{1}$ The status of the child in the South African and Islamic law of intestate succession is first investigated. Thereafter, the status of the child in the South African and Islamic law of testate succession is discussed. The article further looks at the possibility of applying the Islamic law of succession provisions concerning a Muslim child born out of wedlock to the distribution of a deceased estate within the South African legal framework. The article concludes with an analysis of the findings and makes recommendations.

This article analyses the right of a Muslim child born out of wedlock to inherit from his or her deceased parent in terms of the law of succession. ${ }^{2}$ Muslims are required by their religion to ensure that, upon their demise, their estates are distributed in terms of the Islamic law of succession. ${ }^{3}$ This article

It should be noted that a child born out of wedlock is currently referred to as a child born from unmarried parents, which is the more modern term. The term "born out of wedlock" is used here as it is the wording found in the Intestate Succession Act 81 of 1987, which is analysed in this article.

2 South African Muslims follow the religion of Islaam. These persons constitute a religious minority group. The laws found within the religion of Islaam find its basis in two primary sources known as the Quraan and Sunnah.

3 It should be noted that Muslims believe that the Quraan is the word of Allaah (God Almighty). See Khan The Noble Qur'an: English Translation of the Meanings and Commentary $1404 \mathrm{H}$ (4) 13 , where it states "[t]hese are the limits (set by) Allah (or 
investigates the application of the Islamic law of succession provisions concerning a Muslim child born out of wedlock to the distribution of a deceased estate within the South African legal framework. The scenario that is looked at throughout this article assumes a Muslim couple (husband $\mathrm{C}$ and wife $D$ ) are married to each other in terms of Islamic law. Three children are born from the relationship - X, a son, $Y$, another son, and $Z$, a daughter. $X$ was born two months before $C$ and $D$ concluded their Islamic marriage, $Y$ was born two years after conclusion of the Islamic marriage, and $Z$ was born four years after conclusion of the Islamic marriage. $C, D, X, Y$ and $Z$ are all Muslims in terms of this scenario. This article looks at the various possibilities of how $X$ (the child born out of wedlock) would inherit from his deceased parent should his mother or father die either without a will (intestate), or with a will (testate). The right of a child born out of wedlock to inherit from the intestate estate of his or her deceased parent prior to 1987 is looked at by way of introduction. Thereafter the position after 1987 is discussed regarding both the South African and Islamic laws of intestate and testate succession. The options available to a parent to ensure that a child born out of wedlock would inherit from his or her estate within the South African context are then looked at. The article concludes with an overall analysis of the findings, and recommendations are made as to a way forward in this regard.

\section{INTESTATE SUCCESSION LAW WITHIN THE SOUTH AFRICAN CONTEXT}

In terms of Islamic law, a person is deemed to be married upon conclusion of certain requisites found within the religion of Islaam - the meeting of these requisites is referred to hereafter as an Islamic marriage. South African Muslims also have the option of concluding a marriage in terms of South African law (in addition to the Islamic marriage). Such a marriage is referred to hereafter as a civil marriage. It should be noted that, for purposes of this article, $C$ and D have concluded only an Islamic marriage and have opted not to enter into an additional civil marriage. ${ }^{4}$

The South African law of intestate succession applies where a deceased (including a South African Muslim deceased who was married in terms of Islamic law) did not bequeath his or her net estate in terms of a will prior to his or her death. ${ }^{5}$ The South African law of intestate succession is applicable to that part of his or her estate not governed by a will. The South African law

ordainments as regards laws of inheritance), and whosoever obeys Allah and His Messenger (Muhammad PBUH) will be admitted to Gardens under which rivers flow (in Paradise), to abide therein, and that will be the great success"; and 4(14), where it states "[w]hosoever disobeys Allah and His Messenger (Muhammad PBUH), and transgresses His limits, He will cast him into the Fire, to abide therein; and he shall have a disgraceful torment." The number in brackets refers to the chapter number of the Quraan. The number outside the brackets refers to the verse in the chapter.

4 This is done to highlight how South African law applies to children born from Islamic marriages.

5 See Reform of Customary Law of Succession and Regulation of Related Matters Act 11 of 2009 and Intestate Succession Act 81 of 1987. The net estate refers to the estate left behind by a deceased person, less his or her liabilities. The liabilities would include the funeral costs, debt, and administration costs. 
of intestate succession is governed primarily by the Intestate Succession Act $^{6}$ (common law of intestate succession) and the Reform of Customary Law of Succession and Regulation of Related Matters Act (customary law of intestate succession). ${ }^{7}$ The contents of these two Acts are similar with some minor variations. The main difference (relevant to this article) lies in the fact that the customary law of intestate succession provides for a larger number of persons in the category of descendants (including children). ${ }^{8}$ It additionally includes acceptance and union ties as a basis to inherit as descendants in terms of intestate succession law. ${ }^{9}$ A further discussion on this issue is beyond the scope of this article.

Prior to 1988 , a child born out of wedlock did not qualify to inherit from the intestate estate of his or her deceased "father" in terms of South African law. However, he or she did qualify to inherit from his or her deceased mother. ${ }^{10}$ The status of a child born out of wedlock was changed in 1988 when the Intestate Succession Act came into operation. ${ }^{11}$ Section 1(2) of the Intestate Succession Act states: "Illegitimacy shall not affect the capacity of one blood relation to inherit the intestate estate of another blood relation." 12 A child born out of wedlock is therefore now entitled to inherit as a descendant of both parents in terms of the South African law of intestate succession. $X$ would now be entitled to inherit from the intestate estate of $D$, his deceased mother, as well as from the deceased estate of $\mathrm{C}$, his deceased father. ${ }^{13}$

681 of 1987 (Intestate Succession Act).

711 of 2009 (Reform of Customary Succession Act).

8 This is highlighted as the article looks at the rights of children born out of wedlock.

9 See $s 1$ of the Reform of Customary Succession Act, which states that a descendant "means a person who is a descendant in terms of the Intestate Succession Act, and includes (a) a person who is not a descendant in terms of the Intestate Succession Act, but who, during the lifetime of the deceased person, was accepted by the deceased person in accordance with customary law as his or her own child." This could be referred to as an acceptance tie. An example of where an acceptance tie applies to a person would be where $\mathrm{X}$ (who practises African culture) accepts a person (non-biological child) as his own child in accordance with customary law. The child would be deemed his descendant for intestate succession purposes. See s 1(a) of the Reform of Customary Succession Act. This tie is not recognised in common law. Customary law also recognises a tie based on union, which could be termed a union tie. An example is where $X$ enters into a union with a woman in accordance with customary law for the purpose of providing him with children. The woman would be regarded as the descendant of $X$ for purposes of the Intestate Succession. See s $1(b)$ read with s 2(b) of the Reform of Customary Succession Act, which states "a woman, other than the spouse of the deceased, with whom he had entered into a union in accordance with customary law for the purpose of providing children for his spouse's house must, if she survives him, be regarded as a descendant of the deceased".

10 See De Waal and Schoeman-Malan Law of Succession (2015) 30-31. It should be noted that a child born (or even conceived) out of wedlock is also entitled to inherit from the mother in terms of Islamic law.

11 See De Waal and Schoeman-Malan Law of Succession 30-31.

12 See s 1(2) of the Intestate Succession Act, which states: "[n]otwithstanding the provisions of any law or the common or customary law, but subject to the provisions of this Act and sections 40(3) and 297(1)( $f$ ) of the Children's Act, 2005 (Act No. 38 of 2005), having been born out of wedlock shall not affect the capacity of one blood relation to inherit the intestate estate of another blood relation."

13 It should be noted that $Y$ and $Z$ are deemed to born from married parents in terms of South African law, as the Islamic Marriage is recognised in terms of $s 1$ of the Children's Act 38 of 2005 where it states that a "'marriage' means a marriage - (a) recognised in terms of South 
Section $1(b)$ of the Intestate Succession Act is now looked at as a case study to illustrate how the South African law of intestate succession impacts on the rights $\mathrm{X}, \mathrm{Y}$ and $\mathrm{Z}$. Section $1(b)$ of the Intestate Succession Act states:

"[i]f after the commencement of this Act a person (hereinafter referred to as the 'deceased') dies intestate, either wholly or in part, and - ... (b) is survived by a descendant, but not by a spouse, such descendant shall inherit the intestate estate."

For example, s $1(b)$ would apply where $\mathrm{C}$, the father, dies leaving behind a net estate of R150 000. He also leaves behind son X (born out of wedlock), son $Y$ (born in wedlock) and daughter $Z$ (born in wedlock) as his only relatives. $X$ would inherit $R 50000, Y$ would inherit $R 50000$ and $Z$ would inherit R50 000. The fact that $X$ was conceived out of wedlock has no impact on the distribution in this scenario. The same distribution would apply in the event where $D$, the mother, leaves behind a net estate of R150 000, and son $X$ (born out of wedlock), son $Y$ (born in wedlock) and daughter $Z$ (born in wedlock) as her only relatives. $X$ would inherit R50 000, $Y$ would inherit R50 000 and Z would inherit R50 000.14 It can clearly be seen that the provision is gender neutral.

The Islamic law of succession provisions are not the same as the South African law of succession provisions in the above scenario. ${ }^{15}$ This can be

African law or customary law; or (b) concluded in accordance with a system of religious law subject to specified procedures."

$14 \mathrm{~S} 1(b)$ of the Intestate Succession Act.

15 There are 35 verses in Al Quraan that refer to succession laws. See Hussain The Islamic Law of Succession (2005) 29. There are, however, only three verses in Al Quraan that provide specific details of succession laws. These three verses are Al Quraan (4) 11, 12 and 176. The prophetic traditions elaborate and clarify how the verses must be interpreted and applied. See Hussain The Islamic Law of Succession 29. Al Quraan (4) 11 states: "Allah commands you as regards your children's (inheritance); to the male, a portion equal to that of two females; if (there are) only daughters, two or more, their share is two thirds of the inheritance; if only one, her share is half. For parents, a sixth share of inheritance to each if the deceased left children; if no children, and the parents are the (only) heirs, the mother has a third; if the deceased left brothers or (sisters), the mother has a sixth. (The distribution in all cases is) after the payment of legacies he may have bequeathed or debts. You know not which of them, whether your parents or your children, are nearest to you in benefit, (these fixed shares) are ordained by Allah. And Allah is Ever All-Knower, All-Wise." See Khan The Noble Qur'an: English Translation of the Meanings and Commentary 1404H (4) 11. Al Quraan (4) 12 states: "[i]n that which your wives leave, your share is a half if they have no child; but if they leave a child, you get a fourth of that which they leave after payment of legacies that they may have bequeathed or debts. In that which you leave, their (your wives) share is a fourth if you leave no child; but if you leave a child, they get an eighth of that which you leave after payment of legacies that you may have bequeathed or debts. If the man or woman whose inheritance is in question has left neither ascendants nor descendants, but has left a brother or a sister, each one of the two gets a sixth; but if more than two, they share in a third; after payment of legacies he (or she) may have bequeathed or debts, so that no loss is caused (to anyone). This is a Commandment from Allah; and Allah is Ever All-Knowing, Most-Forbearing." See Khan The Noble Qur'an: English Translation of the Meanings and Commentary 1404H (4) 12. Al Quraan (4) 176 states: "[t]hey ask you for a legal verdict. Say: 'Allah directs (thus) about Al-Kalalah (those who leave neither descendants nor ascendants as heirs). If it is a man that dies, leaving a sister, but no child, she shall have half the inheritance. If (such a deceased was) a woman, who left no child, her brother takes her inheritance. If there are two sisters, they shall have twothirds of the inheritance; if there are brothers and sisters, the male will have twice the share of the female. (Thus) does Allah make clear to you (His Law) lest you go astray. And Allah is the All-Knower of everything." See Khan The Noble Qur'an: English Translation of the 
seen by looking at the example of where $\mathrm{C}$, the father, dies leaving behind a net estate of R150 000. ${ }^{16} \mathrm{He}$ also leaves behind son X (born out of wedlock), son $Y$ (born in wedlock) and daughter $Z$ (born in wedlock) as his only relatives. $\mathrm{X}$ would not inherit as he was born out of wedlock, ${ }^{17} \mathrm{Y}$ would inherit R100000 and $Z$ would inherit R50 000. The fact that $X$ was conceived out of wedlock has an impact on the distribution in this scenario, as he does not inherit. ${ }^{18} \mathrm{~A}$ different distribution would apply in terms of the Islamic law of succession in the event that $D$, the mother, passes away leaving behind a net estate of R150 000, and son X (born out of wedlock), son $Y$ (born in wedlock) and daughter $Z$ (born in wedlock) as her only relatives. $X$ would inherit $R 60000, Y$ would inherit $R 60000$ and $Z$ would inherit R30 000.19 The fact that $X$ was conceived out of wedlock does not have an impact on the right of $X$ to inherit from the estate of $D$, his mother,

Meanings and Commentary 1404H (4) 176. See also Khan The Translation of the Meanings of Sahih Al Bukhari 2004 (724) vol 8, 477, where it states: "[t]he Prophet said, 'Give the Fara'id (the shares of the inheritance that are prescribed in the Qur'an) to those who are entitled to receive it. Then whatever remains, should be given to the closest male relative of the deceased." The number in brackets (after the year of publication) refers to the number of the hadeeth in the book.

16 It should be noted that Muslims are required in terms of their religion to ensure that their estates are distributed in terms of the Islamic law of succession. See Khan The Noble Qur'an: English Translation of the Meanings and Commentary 1404H (4) 13 and 14, where it states: "[t]hese are the limits (set by) Allah (or ordainments as regards laws of inheritance), and whosoever obeys Allah and His Messenger (Muhammad [PBUH]) will be admitted to Gardens under which rivers flow (in Paradise), to abide therein, and that will be the great success. And whosoever disobeys Allah and His Messenger (Muhammad [PBUH]), and transgresses His limits, He will cast him into the Fire, to abide therein; and he shall have a disgraceful torment."

17 It is interesting to note that $X$ would have inherited in terms of Islamic law (in this example) if he were conceived out of wedlock, on condition that he was born six months or more after the marriage was concluded between his parents. See Council of Ulamaa Eastern Cape ((2021) http://www.councilofulama.co.za/index.php?option=com_content\&view=article\&id= 1086: child-conceived-before-marriage \&catid=49:marriage\&ltemid $=56$ (accessed 2021-0129)), where it states: "[t]he Fuqaha (jurists) mentions that if one was to marry a woman whom one had impregnated and after six months the child is born then the child will be considered legitimate and will be attributed to the father and will inherit from him. If the child is born before six months, then it will be known as a child of Zina (illegitimate) and will not be attributed to the father but will be attributed to the mother and will inherit from her." This is also the view followed by the Muslim Judicial Council (SA) based in the Western Cape. See Muslim Judicial Council (SA) Fatwa Committee "MJC Position on Succession Law and Related Matters" (2017) document on file with the author of this article.

18 See Khan The Noble Qur'an: English Translation of the Meanings and Commentary 1404H (4) 11, where it states: "Allah commands you as regards your children's (inheritance); to the male, a portion equal to that of two females." It must be noted here that $s$ 9(4) of the Constitution of the Republic of South Africa, 1996 (Constitution) prohibits discrimination based on sex. A further discussion on this issue is however beyond the scope of this article. See s 9 of the Constitution, where it states "(3) The State may not unfairly discriminate directly or indirectly against anyone on one or more grounds, including race, gender, sex, pregnancy, marital status, ethnic or social origin, colour, sexual orientation, age, disability, religion, conscience, belief, culture, language and birth. (4) No person may unfairly discriminate directly or indirectly against anyone on one or more grounds in terms of subsection (3)."

19 See Khan The Noble Qur'an: English Translation of the Meanings and Commentary 1404H (4) 11, where it states: "Allah commands you as regards your children's (inheritance); to the male, a portion equal to that of two females." 
but has an impact on his right to inherit from the estate of $\mathrm{C}$, his father. ${ }^{20} \mathrm{C}$ has a number of options if he wishes to ensure that son $X$ (born out of wedlock) will inherit in terms of the Islamic law of succession. ${ }^{21}$ The option available to $C$ within the Islamic law of intestate succession is looked at under this heading 2, whereas, the options available to him within the Islamic law of testate succession is looked at under heading 3 of this article.

There is consensus by the Islamic scholars that, in the absence of some valid link, a child born out of wedlock would not qualify to inherit as an intestate beneficiary of his or her biological father in terms of Islamic law. ${ }^{22} \mathrm{~A}$ possible link would be an acknowledgment by the biological father in this regard. The father $C$ can thus ensure that son $X$ (born out of wedlock) inherits from his intestate estate by acknowledging that he is the father of $X$. There are however differences of opinion regarding the validity of the acknowledgment. The reason for the differences of opinion is primarily based on the understanding of the hadeeth of the Prophet Muhammad (Peace Be Upon Him), where he states: "the child is for the owner of the bed, and the adulterer receives the stones." ${ }^{23}$ This hadeeth would apply where, for example, husband $\mathrm{J}$ and wife $\mathrm{K}$ are married to each other in terms of Islamic law, and husband $L$ and wife $M$ are also married to each other in terms of Islamic law. If $\mathrm{L}$ impregnates $\mathrm{K}$, then the child born from the pregnancy would be attributed to $\mathrm{J}$, and not L. This is because the owner of the bed would be the husband of $\mathrm{K}$ in this case. The bed refers to $\mathrm{K}$, and $\mathrm{L}$ would be deemed the adulterer as stated in the hadeeth. ${ }^{24}$

The question then arises as to whether the situation would be different where the parties who engaged in the sexual act causing the pregnancy were both unmarried, as is the scenario stated at the beginning of this article. Neither $\mathrm{C}$ nor $\mathrm{D}$ was married to other persons when $\mathrm{X}$ was conceived. The majority opinion in this regard is that the fornicator cannot have the child attributed to him by way of acknowledgment as the hadeeth

20 It should be noted that children conceived out of wedlock are automatically entitled to inherit from their deceased mother but not automatically from their deceased father. A child born out of wedlock is disqualified from inheriting from his or her deceased father as an intestate beneficiary in terms of Islamic law.

21 It should be noted that it is possible for a child born in wedlock not to inherit from his father if he was conceived out of wedlock. Islamic law looks at the moment of conception and not the moment of birth.

22 See Al Subaa'ee M Sharh Al Qaanoon Al Ahwaal Al Shakhshiyyah 3ed (2000) vol 2 part 3 173.

23 See Khan The Translation of the Meanings of Sahih Al Bukhari 2004 (741) vol 8 490, where it relates the narration: "Utba (bin Abi Waqqas) said to his brother Sa'd, 'The son of the slave girl of Zam'a is my son, so be his custodian.' So when it was the year of the Conquest of Mecca, Sa'd took that child and said, 'He is my nephew, and my brother told me to be his custodian.' On that, 'Abd bin Zam'a got up and said, 'But the child is my brother, and the son of my father's slave girl as he was born on his bed.' So they both went to the Prophet (噄). Sa'd said, 'O Allah's Apostle! (This is) the son of my brother and he told me to be his custodian.' Then 'Abd bin Zam'a said, '(But he is) my brother and the son of the slave girl of my father, born on his bed.' The Prophet (䊽) said, 'This child is for you. O 'Abd bin Zam'a, as the child is for the owner of the bed, and the adulterer receives the stones.' He then ordered (his wife) Sauda bint Zam'a to cover herself before that boy as he noticed the boy's resemblance to "Utba. Since then the boy had never seen Sauda till he died."

24 It should be noted that the owner of the bed could either be the woman's husband as in the scenario of $\mathrm{J}, \mathrm{K}, \mathrm{L}$ and $\mathrm{M}$; or the slave master as in the case stated in the hadeeth stated above. A further discussion on this issue is beyond the scope of this article. 
specifically states that the child is for the owner of the bed. ${ }^{25}$ There is, however, a minority opinion stating that there is nothing preventing the fornicator from acknowledging that the child is his, as there is no owner of the bed present. ${ }^{26}$ It is quite interesting to note that the Muslim Judicial Council (SA) based in the Western Cape supports the minority opinion and advises it should be considered when necessary. ${ }^{27}$ It is submitted that a person in the position of $\mathrm{C}$ should make use of the acknowledgment provision in order to have both his sons inherit in terms of the Islamic law of

25 The term "adulterer" is used where a party is married when the sexual act was committed whereas the term "fornicator" is used where the party is not married.

26 Al Munajjid ("230367: What is the ruling on calling an illegitimate child after the father?" https://islamqa.info/en/answers/230367/what-is-the-ruling-on-calling-an-illegitimate-childafter-the-father (accessed 2019-04-12)) states "1. That the illegitimate child is not to be attributed to the zaani even if he acknowledges him and names him after himself. This is the view of most of the scholars of the four madhhabs, and of the Zaahiris (literalists) and others. Based on this view, the illegitimate child - whether male or female - is not to be attributed to the zaani and is not to be described as his child; rather he is to be attributed to his mother, and he is a mahram to her and inherits from her like her other children. Fatwas were issued on the basis of this view by Shaykh Ibn Ibraaheem, as in his Fataawa $(11 / 146)$; Shaykh Ibn Baaz, as in Majmoo' al-Fataawa (18/124); and by the Standing Committee (alLajnah ad-Daa'imah, 20/387). That is because the Prophet (blessings and peace of Allah be upon him) said: "The child is to be attributed to the bed (i.e., to the husband) and the adulterer deserves nothing." Agreed upon. The relevant point here is that the Prophet (blessings and peace of Allah be upon him) did not describe the child as belonging to anyone other than the bed (i.e., the husband), and he said that the adulterer did not deserve anything at all. Attributing the child to the adulterer is attributing the child to someone other than the husband. The words: "The child is to be attributed to the husband" imply that attribution of the child is to be to the marriage only. 2. That if the zaani acknowledges his illegitimate child, then he is to be attributed to him. This is the view of 'Urwah ibn az-Zubayr, Sulaymaan ibn Yasaar, al-Hasan al-Basri, Ibn Sireen, Ibraaheem an-Nakha'i, and Ishaaq ibn Raahawayh, as was narrated from them by Ibn Qudaamah in al-Mughni (9/123). This view was favoured by Shaykh al-Islam Ibn Taymiyah (may Allah have mercy on him) and his student Ibn al-Qayyim. Among contemporary scholars it was also favoured by Shaykh Muhammad Rasheed Rida in Tafseer al-Manaar (4/382), and by Shaykh Ibn 'Uthaymeen (may Allah have mercy on him), as in ash-Sharh al-Mumti' (12/127). That is because this child was born from his sperm, so he is his son in reality, and there is no clear, sound, shar'i evidence to indicate that he should not be attributed to him. With regard to the hadith "The child is to be attributed to the bed (i.e., to the husband) and the adulterer deserves nothing", it refers to the case where there is a marriage, and the issue under discussion here has to do with a case where there is no marriage. This is supported by what is mentioned in the story of the devoted worshipper Jurayj, when he spoke to the child whose mother had committed zina with the shepherd: "He said: 'Who is your father, O child?' The child said: 'The shepherd."' Agreed upon. The speech of this infant was by way of a miracle and extraordinary event bestowed by Allah, and he stated that the shepherd was his father, even though the relationship was one of zina. This proves that paternity may be attributed to the zaani. Moreover, the Lawgiver seeks to protect lineages and take care of children, and to give them the best upbringing and protect them from being lost. We have previously discussed the matter in detail and explained the different scholarly opinions concerning it, and the evidence for each view, in the answer to question no. 192131. Conclusion: The view that it is forbidden or permissible (to attribute an illegitimate child to his father) are two scholarly views that carry weight. This issue is one of the matters that are open to ijtihaad, so every case should be examined on its own merits. If the child will miss out on some religious or worldly interests (by not being attributed to his father), then we should adopt the view that it is permissible to attribute him to his father, in the interest of protecting him and ensuring that he will be taken care of, which is a legitimate shar'i interest. And Allah knows best."

27 Muslim Judicial Council (SA) Fatwa Committee "MJC Position on Succession Law and Related Matters" (2017) document on file with the author of this article. 
intestate succession. It is further submitted that the acknowledgment should be done by way of a sworn affidavit in this regard. It should be noted that acknowledgment on its own would not be sufficient to ensure that the net estate of $\mathrm{C}$ is distributed in terms of Islamic law within the South African context. It would further be required that $\mathrm{C}$ should draft a will stating his wishes. This is looked at in the next section.

\section{TESTATE SUCCESSION LAW WITHIN THE SOUTH AFRICAN CONTEXT}

South African law recognises the common-law principle of freedom of testation. ${ }^{28}$ The freedom generally allows a person to bequeath assets in his or her estate as he or she pleases. ${ }^{29}$ The principle of freedom of testation can be used by $\mathrm{C}$, the father, to ensure that his net estate devolves in terms of Islamic law. Two situations should be distinguished in this regard. The first situation is where $\mathrm{C}$ acknowledges paternity of $\mathrm{X}$ (born out of wedlock) by way of affidavit. The second situation is where he does not acknowledge the paternity of his biological son.

In the instance where $\mathrm{C}$ acknowledges paternity, he could have made use of a will to ensure that his estate is distributed in terms of the Islamic law of intestate succession. This could be done using three methods.

The first method is for $\mathrm{C}$ to state in his will that each of his two sons (without mentioning their names) should inherit R60000 and that his daughter (without mentioning her name) should inherit R30 000. These types of stipulation in a will are referred to as class bequests. The question then arises as to whether $X$ is the child of $C$ for the purposes of the South African law of testate succession even though he was born out of wedlock. Section $2 \mathrm{D}(1)(c)$ of the Wills Act 7 of 1953 deals with the interpretation of wills. The section states "the fact that any person was born out of wedlock shall be ignored in determining his relationship to the testator or another person for the purposes of a will". The provision in the will is thus valid and enforceable in terms of both Islamic law and South African law. It should be highlighted here that $C$ is making use of the South African law of testate succession within the South African context to apply the Islamic law of intestate succession as required by him in terms of Islamic law.

The second method that can be used by $C$ to ensure that his estate is distributed in terms of the Islamic law of intestate succession is to state in his will that he bequeaths R60 000 in favour of $X$ (giving full details of his son), R60 000 in favour of $Y$ (giving full details of his son) and R30 000 in favour of $Z$ (giving full details of his daughter). These bequests are less complicated as the beneficiaries are clearly defined. The issue concerning $X$ having been born out of wedlock does not feature in this instance. The provision in the will is thus valid and enforceable in terms of Islamic law and South African law.

\footnotetext{
28 Jamneck "Freedom of Testation" in Jamneck and Rautenbach The Law of Succession in South Africa (2009) 115.

29 There are a few limitations to this freedom.
} 
The third method that can be used by $C$ to ensure that his estate is distributed in terms of the Islamic law of intestate succession is to state in his will that his estate must be distributed in terms of the Islamic law of intestate succession and that the executor of his estate must approach an institution like the Muslim Judicial Council (SA), for example, to execute an Islamic Distribution Certificate stating who his Islamic law beneficiaries are at the time of his death. ${ }^{30}$ This could be referred to as an Islamic will. ${ }^{31}$ It would be advisable for the executor to approach an institution that recognises as valid the minority opinion regarding acknowledgment in order for the child to be listed as a beneficiary on the certificate. It is recommended that the testator should also state in his will that he has acknowledged paternity of $X{ }^{32} \mathrm{He}$ should then also attach the sworn affidavit of acknowledgment to his will in this regard. The Islamic Distribution Certificate would then state that $X$ (acknowledged son) should inherit two-fifths of R150 $000=R 60000, Y$ (son) should inherit two-fifths of R150 $000=R 60000$, and $Z$ (daughter) should inherit one-fifth of R150000 $=R 30000 .{ }^{33}$ The provision in the will would therefore be valid and enforceable in terms of South African law as well as Islamic law.

Where $C$ does not acknowledge paternity of $X$ (his son born out of wedlock), it would then mean that $X$ would not be entitled to inherit in terms of the Islamic law of intestate succession. The Islamic law of testate succession provides that a testator may bequeath up to a maximum of onethird of his or her net estate in favour of a person who does not inherit in terms of the Islamic law of intestate succession. ${ }^{34} \mathrm{C}$ could therefore bequeath up to a maximum of one-third of the net estate in favour of $X$ in terms of a will. $C$ could, for example, state in his will that he bequeaths R37 500 (which is less than one-third of R150 000) in favour of X (son born out of wedlock). He can further state in his will that $Y$ (son born in wedlock) should inherit R75 000 and that his daughter Z (who was born in wedlock)

30 The Muslim Judicial Council (SA) offers the services of issuing Islamic distribution certificates. See Muslim Judicial Council (SA) "Fatwa" (2020) https://mjc.org.za/ departments/fatwa/ (accessed 2020-04-13).

31 The interpretation of the provisions found in an Islamic will was looked at by the Constitutional Court in Moosa v Minister of Justice and Correctional Services [2018] ZACC 19. The case concerned renunciation of benefits by beneficiaries who were listed in the Islamic Distribution Certificate issued by the Muslim Judicial Council (SA). See Abduroaf "An Analysis of Renunciation in terms of s 2C(1) of the Wills Act 7 of 1953 in light of the Moosa NO and Others v Harnaker and Others judgment" 20197 Electronic Journal of Islamic and Middle Eastern Law 1521 for a discussion on the consequences of renunciation in terms of South African law and Islamic law.

32 It is interesting to note that the Muslim Judicial Council (SA) based in the Western Cape supports the minority opinion and advises it should be considered when necessary. See Muslim Judicial Council (SA) Fatwa Committee "MJC Position on Succession Law and Related Matters" (2017) document on file with the author of this article.

33 See Khan The Noble Qur'an: English Translation of the Meanings and Commentary 1404H (4) 11, where it states: "Allah commands you as regards your children's (inheritance); to the male, a portion equal to that of two females."

34 See Khan The Translation of the Meanings of Sahih Al Bukhari 2004 (6) vol 4 4, where it is narrated that Ibn Abbaas said: "I recommend that people reduce the proportion of what they bequeath by will to the fourth (of the whole legacy), for Allah's Messenger (踣) said, 'Onethird, yet even one third is too much."' 
should inherit R37 $500 .{ }^{35}$ It is interesting to note that $X$ and $Z$ inherit equal shares.

\section{$4 \quad$ CONCLUSION}

This article looked at the right of a Muslim child born out of wedlock to inherit from his or her deceased parents within the South African context. The findings have shown that the status of the child in terms of the Islamic law of succession and the South African law of succession is quite different and that Muslims are required in terms of Islamic law to ensure that their estates are distributed in terms of the Islamic law of succession upon their demise. It has also shown that children conceived and born within Islamic marriages are deemed children born out of wedlock for purposes of South African law. The findings have also shown that there are ways in which a testator or testatrix can ensure that his or her estate devolves in terms of Islamic law. This includes making use of succession law provisions found within the South African context. It is recommended that South African Muslims should make use of the options available to put children conceived out of wedlock on a similar footing to those conceived in wedlock.

35 See Khan The Noble Qur'an: English Translation of the Meanings and Commentary $1404 \mathrm{H}$ (4) 11, where it states: "Allah commands you as regards your children's (inheritance); to the male, a portion equal to that of two females." 